\title{
Molecular phylogeny of Anatolian and Cypriot donkey populations based on mitochondrial DNA and Y-chromosomal STRs
}

\author{
Bengi CINAR KUL ${ }^{1}$, Nuket BILGEN ${ }^{1}$, Bilal AKYUZ ${ }^{2}$, Okan ERTUGRUL ${ }^{1}$ \\ ${ }^{1}$ Ankara University, Faculty of Veterinary Medicine, Department of Genetics, Ankara; ${ }^{2}$ Erciyes University, Faculty of Veterinary \\ Medicine, Department of Genetics, Melikgazi, Kayseri, Turkey.
}

\begin{abstract}
Summary: Domestication centers and the lineages of the wild ass contributing to modern domestic donkey population are still unknown, except the Nubian wild ass. This study is designed to fill the gaps about Anatolian donkey domestication. A total of 68 samples of Anatolian donkeys obtained from Turkey and seven donkeys from Cyprus were analyzed for D-loop and cytochrome $b$ gene regions. Males were also genotyped with three equine Y-chromosomal short tandem repeats (STRs) namely Eca.YM2, Eca.YP9 and Eca.YE1. While the haplotype and nucleotide diversities $(h=0.756 \pm 0.0500$ and $\pi=0.1688 \pm 0.0012)$ obtained from D-loop sequences of Anatolian donkey population were found to be moderately high, the Cypriot donkey population were found dramatically reduced $(h=0.524 \pm 0.209$ and $\pi=0.00176 \pm 0.001)$ than those in Turkey. Only $35 \%$ of the Anatolian donkeys were clustered in Clade 1 linked with Nubian ass, while the remaining 65\% and $100 \%$ of the Cypriot donkeys were clustered in Clade 2 . In the present study, Clade 2 was genetically divergent from Somali lineage and from Asiatic wild asses. Thus, they were excluded from to be ancestor of Anatolian and Cypriot donkey populations. A total of 17 and 4 nucleotide differences, discriminating 15 and 6 haplotypes, were defined for D-loop and cytochrome b sequences, respectively. Analyzed Y chromosomal STRs were found to be monomorphic. The allele size of 109, 190 and 195 were identified for Eca.YM2, Eca.YP9 and Eca.YE1, respectively.
\end{abstract}

Key words: Anatolian donkey, Cypriot donkey, cytochrome b, D-loop, Y-chromosomal STRs.

\section{Anadolu ve Kıbrıs eşek populasyonlarında mitokondriyal ve Y-kromozomal STR'larına dayanan moleküler filogeni}

Özet: Evciltme bölgeleri ve modern evcil eşek populasyonuna katkıda bulunan soylar, Nubian yaban eşeği hariç, hala bilinmemektedir. Bu çalışma Anadolu eşeğinin evciltmesi hakkındaki boşlukların doldurulması için tasarlanmıştır. Türkiye'den 68 Anadolu eşeği ve Kıbrıs'tan yedi eşek, D-loop ve cytochrome b gen bölgeleri açısından analiz edilmiştir. İncelenen örneklerden 30 erkek aynı zamanda ata ait Eca.YM2, Eca.YP9 ve Eca.YE1 isimli üç adet Y-kromozomal kısa ardışık tekrar dizileri (STRlar) ile genotiplendirilmiştir. Anadolu eşek populasyonu D-loop sekanslarından elde edilen haplotip ve nükleotid çeşitliliği $(h=0.756 \pm 0.0500$ ve $\pi=0.1688 \pm 0.0012)$ orta düzeyde yüksek bulunmuşken, Kıbrıs eşek populasyonunda büyük ölçüde düşük $(h=0.524 \pm 0.209$ ve $\pi=0.00176 \pm 0.001$ ) bulunmuştur. Anadolu eşeklerinin \%35'i Clade 1'de Nubian yaban eşeği ile kümelenmişken, kalan \%65'i ve Kıbrıs eşeklerinin \%100'ü Clade 2 olarak kümelenmiştir. Sunulan çalışmada Clade 2 Somali soyundan ve Asya yaban eşeklerinden genetik olarak farklı çıkmıştır. Böylece bu soyların Anadolu ve Kıbrıs eşeğinin atası olamayacakları belirlenmiştir. D-loop ve sitokrom bölgeleri için, sırasıyla, 15 ve 6 haplotip ayrımını sağlayan 17 ve 4 nükleotid değişimi belirlenmiştir. Analiz edilen Ykromozomal STR'lar monomorfik bulunmuştur. Eca.YM2, Eca.YP9 ve Eca.YE1 için sirasiyla 109, 190 ve 195 allel büyüklükleri belirlenmiştir.

Anahtar sözcükler: Anadolu eşeği, Kıbrıs eşeği, sitokrom b, D-loop, Y-kromozomal STR.

\section{Introduction}

It is thought that the donkey was domesticated about 5000-6000 years ago and they were essentially used for transport and trade during the ancient civilization over decades. Domestication centers and the lineages of the wild ass contributing to modern domestic donkey population, are still unknown, except the contribution of the Nubian wild ass $(1,10,17,20)$. According to archaeological, historical, and ethnographical sources there are at least two distinct groups of wild asses existed in Africa; The Somali Wild (Equus africanus somaliensis) and the Nubian Wild (Equus africanus africanus) (20). Like in other countries, donkeys have raised for the purpose of transportation in the rural areas of Turkey. In the past, the offspring's donkey and horses, mules were used in wars and other strength needed works because of their improved durability and resistance abilities under harsh physical conditions (22).

Mammalian mitochondrial DNA (mtDNA) is inherited maternally; this inheritance is firstly demonstrated 
Hutchison et al. (8) in the horse-donkey hybrids. Y chromosome represents a paternal counterpart to mtDNA they are both informative for evolutionary and phylogeographic studies. According to phylogenetic analyses results, the animals that are reared in domestication centers like Anatolia, show high genetic diversity in each clade of mtDNA (23). This knowledge was also documented by Cinar Kul and Ertugrul (12) as preservation of mtDNA diversities in Anatolian goats.

This study is designed to fill the gaps about Anatolian donkey domestication. A total of 68 samples of Anatolian donkeys obtained from Turkey and seven donkeys from Cyprus were analyzed for D-loop and cytochrome $b$ gene regions. Thirty of the samples were male and they were also analyzed for three equine $\mathrm{Y}$ chromosomal short tandem repeats (STRs) namely Eca.YM2, Eca.YP9 and Eca.YE1, in addition to mtDNA analyses.

\section{Materials and Methods}

Sample collection: A total of 75 hair samples were collected from Anatolian donkeys raised in different regions of Turkey (Ankara, $n=11$; Kayseri, $n=24$; Mersin, $\mathrm{n}=33$ ) and from Cypriot wild donkeys, free-living in the Karpaz national park, Northern Cyprus $(n=7)$ (Figure 1). Phenol-chloroform method was used for DNA extraction. Purity and quantity of the DNAs were measured using NanoDrop 2000 (Thermo Scientific).

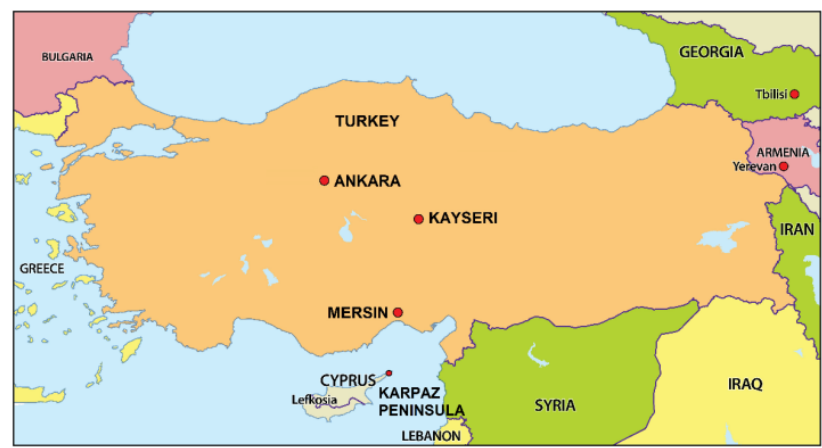

Figure 1. Sampling areas of the Anatolian and Cypriot donkey populations.

Şekil 1. Anadolu ve Kıbrıs eşek populasyonları için örnekleme bölgeleri.

PCR, sequencing and fragment analysis: D-loop and cytochrome $\mathrm{b}$ gene regions were amplified by Polymerase Chain Reaction (PCR) carried out in $25 \mu \mathrm{l}$ reaction volume containing 50ng DNA, 2.5mM $\mathrm{MgCl}_{2}$, $0.2 \mathrm{mM}$ of each dNTP, $0.5 \mu \mathrm{M}$ of each primer (Table 1), $1 \mathrm{X}$ PCR Buffer and $1 \mathrm{U}$ of Taq DNA polymerase (Fermentas, Thermo Fischer Scientific). Thermal cycling was carried out using Mastercycler thermocycler (Eppendorf, USA) with the following conditions: initial denaturation at $94^{\circ} \mathrm{C}$ for $5 \mathrm{~min}$ followed by 35 cycles of denaturation at $94{ }^{\circ} \mathrm{C}$ for $30 \mathrm{sec}$, annealing at $58{ }^{\circ} \mathrm{C}$ for 30 sec extension at $72{ }^{\circ} \mathrm{C}$ for $30 \mathrm{sec}$ and final extension at 72 ${ }^{\circ} \mathrm{C}$ for 5 minutes. PCR products were purified and sequenced for both directions.

Table 1. Amplified regions, primer sequences and their references.

Tablo 1. Yükseltgenen bölgeler, primer dizileri ve referansları.

\begin{tabular}{llc}
\hline Region & Primers, ${ }^{\prime} \rightarrow 3^{\prime}$ & Reference \\
\hline D-loop & F: CCCAAGGACTATCAAGGAAG & 1 \\
& R: TTGGAGGGATTGCTGATTTC & \\
Cytochrome b F: CTGCCGAGACGTTAACTA & 1 \\
& R: GGCTTTGTCTACTGAGAATC & \\
Eca.YM2 & F: TGGTTCAGATGGTGTATTTTGTT & 2 \\
& R: TTTGCAGCCAGTACCTACCTT & \\
Eca.YP9 & F: AAGCACTGCCTTTTGGAATC & 2 \\
& R: AACCCTGGACTTTCTTTTAA & \\
Eca.YE1 & F: CTTCACTCCCGACCAAGAGA & 2 \\
& R: GTGTGTCGTGCCGTGTTTAC & \\
\hline
\end{tabular}

l= Aranguren-Mendez et al., 2004 (1); 2= Wallner et al., 2004 (21).

$1=$ Aranguren-Mendez ve ark., 2004 (1); 2= Wallner ve ark., $2004(21)$

A total of 30 male donkey samples were also amplified by PCR for three equine Y chromosomal STR loci, namely Eca.YM2, Eca.YP9 and Eca.YE1. Forward primers were synthesized by 5' end labeling with fluorescent dyes (Sentromer DNA Ltd, Istanbul, Turkey). Each reaction carried out in $15 \mu \mathrm{l}$ reaction volume containing 50ng DNA, $2 \mathrm{mM} \mathrm{MgCl}_{2}, 0.2 \mathrm{mM}$ of each dNTP, $0.3 \mu \mathrm{M}$ of each primer (Table 1), 1 X PCR Buffer and $1 \mathrm{U}$ of Taq DNA polymerase (Fermentas, Thermo Fischer Scientific). Samples were amplified in a Mastercycler thermocycler (Eppendorf, USA) with the following conditions: initial denaturation step at $94{ }^{\circ} \mathrm{C}$ for $4 \mathrm{~min}$ followed by 30 cycles of $94{ }^{\circ} \mathrm{C}$ for $20 \mathrm{sec}$, annealing for $58{ }^{\circ} \mathrm{C}$ for $15 \mathrm{sec}, 72{ }^{\circ} \mathrm{C}$ for $15 \mathrm{sec}$ and a final extension at $72{ }^{\circ} \mathrm{C}$ for $5 \mathrm{~min}$. Amplicons were denatured in formamide and LIZ 500-bp internal size standard (Applied Biosystems). Fragment analysis was carried out using the capillary electrophoresis by 310 Genetic Analyzer (Applied Biosystems).

Statistical analysis: D-loop and cytochrome-b sequence sets were separately aligned to reference sequences of the domestic donkey (X97337) using Clustal W algorithm implemented in BioEdit sequence alignment editor (6). After trimming the sequences, 325 nucleotides and 251 nucleotides were used for following analysis for D-loop and cytochrome-b, respectively. Obtained haplotypes were compared with available sequences of the domestic donkeys in the GenBank (http://www.ncbi.nlm.nih.gov). D-loop sequences were also aligned to Asian wild asses (Equus kiang, AY569542; Equus hemionus kulan, JX312728; Equus hemionus onager, JX312730), African wild asses (Equus africanus somalicus, AY569545; Equus africanus 
africanus, HM622636) homologous sequences and horse sequence (Equus caballus, AF481232) as an outgroup.

The variable positions, haplotype $(h)$ and nucleotide diversities $(\pi)$ within the donkey populations were calculated by DnaSP (15). Neighbor joining trees based on individual sequences and haplotypic data were constructed by MEGA V6 (18) using Tamura-Nei distances and Kimura 2-parameter distances for D-loop and cytochrome b, respectively. A Median-joining network diagram was created to visualize the genetic relationships between haplotypes of the D-loop regions using PopART (14).

A total of 30 male donkeys were genotyped based on Y chromosomal STRs by using GeneScan program software (Applied Biosystems).

\section{Results}

Genetic diversity of the D-loop region: Haplotype and nucleotide diversities of the sampled population were presented in Table 2. A total of 17 nucleotide differences discriminating 15 haplotypes were obtained from D-loop sequences from 75 donkeys as compared to reference sequences of the domestic donkey. Obtained positions of the polymorphic nucleotides, assigned haplotypes, accession numbers and frequencies were shown in Table 3 for D-loop sequences. New haplotypes were submitted to GenBank (KP763625- KP763630, KP763640).

According to individual D-loop sequences visualized by $\mathrm{NJ}$ tree, a total of 24 Anatolian donkeys were defined closely linked with Nubian lineage (Clade 1, Equus a. africanus), while 44 Anatolian donkeys and 7 Cypriot

Table 2. Haplotype and nucleotide diversity values based on D-loop sequences

Tablo 2. D-loop bölgesi haplotip ve nükleotid çeşitliliği değerleri

\begin{tabular}{lcccc}
\hline \multicolumn{1}{c}{ Region } & $\mathrm{n}$ & Number of haplotpye & $h$ & $P i$-JC \\
\hline Ankara & 11 & 5 & $0.618 \pm 0.164$ & $0.01852 \pm 0.010$ \\
Kayseri & 24 & 7 & $0.692 \pm 0.094$ & $0.01625 \pm 0.009$ \\
Mersin & 33 & 9 & $0.833 \pm 0.049$ & $0.01847 \pm-0.010$ \\
Anatolian Overall & 68 & 14 & $0.756 \pm 0.050$ & $0.01688 \pm 0.0012$ \\
\hline Cyprus & 7 & 3 & $0.524 \pm 0.209$ & $0.00176 \pm 0.001$ \\
\hline
\end{tabular}

n sample size, $h$ haplotype diversity $+/$ - standard deviation, Pi-JC Nucleotide diversity with JC $+/$ - standard deviation.

n örneklem büyüklüğ̈̈, $h$ haplotip çeşitliliği +/- standart sapma, $P i$-JC JC'li nükleotid çeşitliliği +/- standart sapma.

Table 3. Polymorphic nucleotide positions, accession numbers and frequencies of the haplotypes obtained from D-loop sequences of Anatolian and Cypriot donkey populations.

Tablo 3. Anadolu ve Kıbrıs eşek populasyonunda D-loop sekanslarından elde edilen haplotiplerin polimorfik nükleotid pozisyonları ve frekansları.

\begin{tabular}{|c|c|c|c|c|c|c|c|c|c|c|c|c|c|c|c|c|c|c|c|c|}
\hline \multirow[b]{6}{*}{ Haplotype } & \multicolumn{18}{|c|}{ Position $* *$} & \multirow{6}{*}{$\begin{array}{c}\text { Frequencies } \\
\mathrm{AD} ; \mathrm{CD}\end{array}$} & \multirow{6}{*}{$\begin{array}{c}\text { Accession } \\
\text { number }\end{array}$} \\
\hline & 1 & 1 & 1 & 1 & 1 & 1 & 1 & 1 & 1 & 1 & 1 & 1 & 1 & 1 & 1 & 1 & 1 & 1 & & \\
\hline & 5 & 5 & 5 & 5 & 5 & 5 & 5 & 5 & 5 & 5 & 5 & 5 & 5 & 5 & 5 & 5 & 5 & 5 & & \\
\hline & 4 & 4 & 4 & 5 & 5 & 5 & 5 & 5 & 5 & 5 & 5 & 6 & 6 & 6 & 6 & 6 & 6 & 6 & & \\
\hline & 1 & 8 & 9 & 0 & 3 & 6 & 8 & 9 & 9 & 9 & 9 & 2 & 4 & 4 & 5 & 6 & 6 & 9 & & \\
\hline & 1 & 4 & 0 & 3 & 8 & 9 & 0 & 2 & 7 & 8 & 9 & 1 & 4 & 5 & 2 & 2 & 7 & 8 & & \\
\hline ATI1 & $\overline{\mathrm{T}}$ & $\bar{G}$ & $\overline{\mathrm{C}}$ & $\bar{T}$ & $\overline{\mathrm{A}}$ & $\overline{\mathrm{A}}$ & $\overline{\mathrm{A}}$ & $\overline{\mathrm{A}}$ & $\overline{\mathrm{T}}$ & $\overline{\mathrm{C}}$ & $\overline{\mathrm{G}}$ & $\bar{A}$ & $\bar{G}$ & $\overline{\mathrm{A}}$ & $\overline{\mathrm{C}}$ & $\overline{\mathrm{A}}$ & $\overline{\mathrm{A}}$ & $\overline{\mathrm{C}}$ & $32 ; 5$ & AF416594 \\
\hline ATI2 & . & A & $\mathrm{T}$ & $\mathrm{C}$ & . & G & $\mathrm{G}$ & . & . & $\mathrm{T}$ & . & G & A & . & $\mathrm{T}$ & $\mathrm{G}$ & . & $\mathrm{T}$ & $3 ; 0$ & AF416593 \\
\hline SU01 & . & A & $\mathrm{T}$ & $\mathrm{C}$ & . & G & $\mathrm{G}$ & . & . & $\mathrm{T}$ & . & $\mathrm{G}$ & $\mathrm{A}$ & $\mathrm{G}$ & $\mathrm{T}$ & G & . & $\mathrm{T}$ & $1 ; 0$ & AY569523 \\
\hline ATI4 & . & A & $\mathrm{T}$ & $\mathrm{C}$ & . & G & $\mathrm{G}$ & . & . & $\mathrm{T}$ & . & . & A & . & $\mathrm{T}$ & G & . & $\mathrm{T}$ & $9 ; 0$ & AF416596 \\
\hline TR1 & . & . & . & . & G & . & . & . & . & . & . & . & . & . & $\mathrm{T}$ & . & . & . & $3 ; 0$ & KP763625* \\
\hline TR4 & . & A & $\mathrm{T}$ & $\mathrm{C}$ & . & G & . & . & . & $\mathrm{T}$ & . & . & A & G & $\mathrm{T}$ & G & . & $\mathrm{T}$ & $3 ; 0$ & KP763628* \\
\hline TR6 & . & A & $\mathrm{T}$ & $\mathrm{C}$ & . & $\mathrm{G}$ & . & . & . & $\mathrm{T}$ & . & $\mathrm{G}$ & A & $\mathrm{G}$ & $\mathrm{T}$ & G & . & $\mathrm{T}$ & $1 ; 1$ & KP763630* \\
\hline LI12 & . & . & $\mathrm{T}$ & . & . & . & . & . & . & . & . & . & . & . & . & . & . & . & $1 ; 0$ & AY569506 \\
\hline RU01 & . & . & . & . & . & . & $\mathrm{G}$ & . & . & . & . & . & . & . & . & . & . & . & $2 ; 0$ & AY569471 \\
\hline TR3 & . & . & . & . & . & G & . & . & . & . & . & . & . & . & . & . & . & . & $3 ; 0$ & KP763627* \\
\hline TR7 & $\mathrm{C}$ & . & . & . & . & . & . & . & . & . & . & . & . & . & . & . & . & . & $2 ; 0$ & KP763640* \\
\hline TR2 & . & . & . & . & . & G & . & . & $\mathrm{C}$ & . & . & . & . & . & . & . & . & . & $3 ; 0$ & KP763626* \\
\hline TR5 & . & . & . & . & . & . & . & . & . & . & . & . & . & . & . & . & $\mathrm{G}$ & . & $0 ; 1$ & KP763629* \\
\hline KE01 & . & A & $\mathrm{T}$ & $\mathrm{C}$ & . & G & $\mathrm{G}$ & G & . & $\mathrm{T}$ & . & G & A & . & $\mathrm{T}$ & G & . & $\mathrm{T}$ & $3 ; 0$ & AY569503 \\
\hline KE03 & . & A & $\mathrm{T}$ & $\mathrm{C}$ & . & G & . & . & . & $\mathrm{T}$ & . & G & A & . & $\mathrm{T}$ & G & . & $\mathrm{T}$ & $1 ; 0$ & AY569481 \\
\hline
\end{tabular}

$\mathrm{AD}=$ Anatolian donkeys $\mathrm{CD}=$ Cypriot donkeys. * submitted with the present study.

** Nucleotide positions are based on the reference sequence of E. Asinus (X97337).

$\mathrm{AD}=$ Anadolu eşeği; $\mathrm{CD}=\mathrm{K}$ ıbrıs eşeği. * bu çalışma ile belirlenen.

** Nükleotid pozisyonlarında E. Asinus (X97337) referans sekansı temel alınmıştır. 

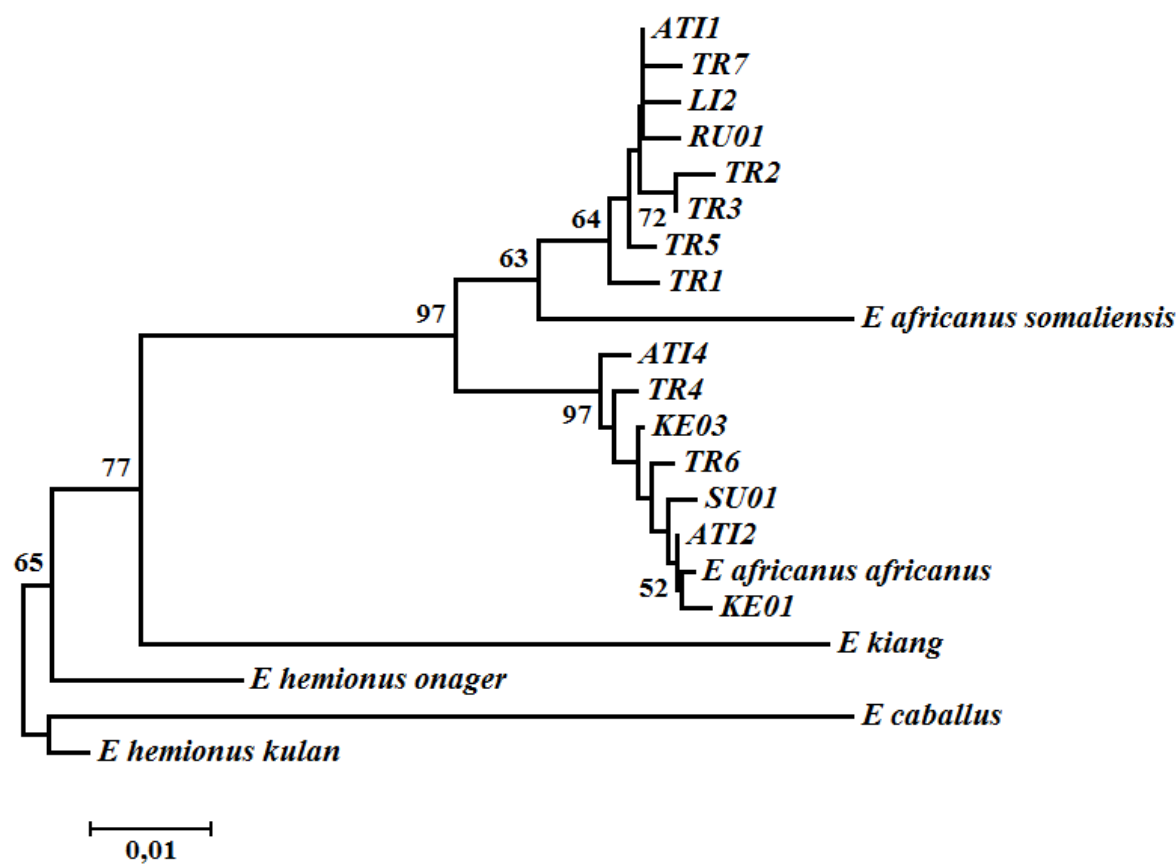

Figure 2. Neighbor Joining tree based on D-loop sequences using Tamura-Nei distances. Numbers represent the bootstrap proportions.

Şekil 2. D-loop sekanslarına ait, Tamura-Nei uzaklık metodu kullanılarak çizdirilen Neighbor Joining ağacı. Sayılar bootstrap değerlerini ifade etmektedir.

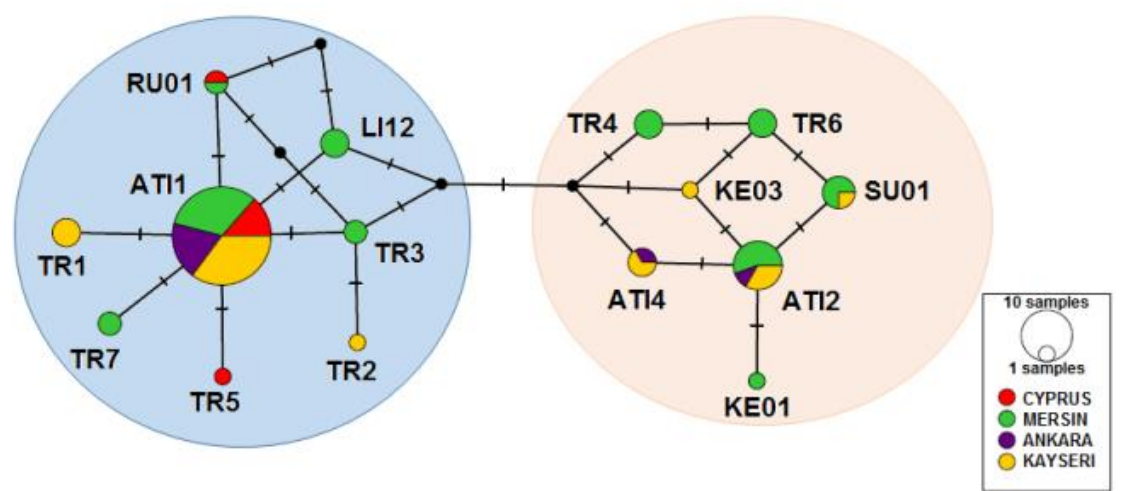

Figure 3. Median joining network of the haplotypes revealed by D-loop region. Şekil 3. D-loop bölgesinden elde edilen haplotiplere ait Median joining ağaci.

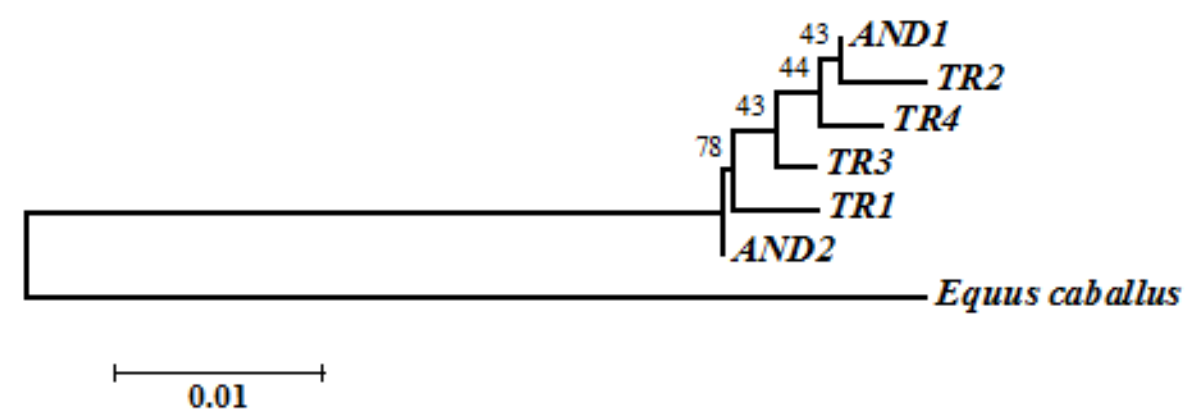

Figure 4. Neighbor Joining tree based on Cytochrome b sequences using K2P. Numbers represent the bootstrap proportions. Şekil 4. Sitokrom b sekanslarına ait, K2P uzaklık metodu kullanılarak çizdirilen Neighbor Joining ağacı. Sayılar bootstrap değerlerini ifade etmektedir. 
donkeys were clustered in Clade 2, but they did not show resemblance to Somali lineage (Equus a. somalicus) (data not shown). Similarly, D-loop haplotypes were divided into two branches in the NJ tree (Fig 2). Star-like clusters were seen around the haplotypes ATI1 and ATI2 in $\mathrm{MJ}$ tree and localization of the haplotypes showed the similar topology with $\mathrm{NJ}$ tree (Figure 3).

Genetic diversity of Cytochrome b region: A total of four nucleotide differences discriminating six haplotypes were obtained from cytochrome b sequences. Haplotype and nucleotide diversities were presented in Table 2. Polymorphic nucleotide positions, assigned haplotypes, their accession numbers and frequencies in the populations were shown in Table 4.

Table 4. Polymorphic nucleotide positions, accession numbers and frequencies of the haplotypes obtained from Cytochrome $b$ sequences of Anatolian and Cypriot donkey populations.

Tablo 4. Anadolu ve Kıbrıs eşek populasyonunda sitokrom b sekanslarından elde edilen haplotiplerin polimorfik nükleotid pozisyonları ve frekansları.

\begin{tabular}{|c|c|c|c|c|c|c|}
\hline \multirow[b]{6}{*}{ Haplotype } & \multicolumn{4}{|c|}{ Position $* *$} & \multirow{6}{*}{$\begin{array}{c}\text { Frequencies } \\
(\mathrm{AD} ; \mathrm{CY})\end{array}$} & \multirow{6}{*}{$\begin{array}{c}\text { Accession } \\
\text { number }\end{array}$} \\
\hline & 1 & 1 & 1 & 1 & & \\
\hline & 4 & 4 & 4 & 4 & & \\
\hline & 4 & 4 & 4 & 5 & & \\
\hline & 1 & 3 & 4 & 9 & & \\
\hline & 8 & 5 & 1 & 1 & & \\
\hline$\overline{\mathrm{AND} 2}$ & 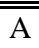 & $\overline{T \mathrm{~T}}$ & $\overline{\mathrm{C}}$ & $\overline{\bar{T}}$ & $37 ; 7$ & "AF380131 \\
\hline AND1 & . & $\mathrm{C}$ & . & . & $18 ; 0$ & AF380130 \\
\hline TR4 & $\mathrm{T}$ & $\mathrm{C}$ & . & . & $7 ; 0$ & KP792642* \\
\hline TR3 & $\mathrm{T}$ & . & . & . & $4 ; 0$ & KP792641* \\
\hline TR1 & $\cdot$ & . & $\mathrm{T}$ & . & $1 ; 0$ & KP792639* \\
\hline TR2 & $\cdot$ & $\mathrm{C}$ & . & $\mathrm{C}$ & $1 ; 0$ & KP792640* \\
\hline
\end{tabular}

$\mathrm{AD}=$ Anatolian donkeys; $\mathrm{CD}=$ Cypriot donkeys $*$ submitted with the present study

** Nucleotide positions are based on the reference sequence of E. Asinus (X97337).

$\mathrm{AD}=$ Anadolu eşeği; $\mathrm{CD}=$ Kıbrıs eşeği. * bu çalışma ile belirlenen ** Nükleotid pozisyonlarında E. Asinus (X97337) referans sekansı temel alınmıştır.

According to cytochrome b haplotype frequencies, more than half of the Anatolian donkey population and all of the Cypriot donkey population were clustered as haplotype AND2. However four unique haplotypes, which are close to AND1, were defined in Anatolian donkeys (Fig 4). New haplotypes were submitted to GenBank (KP792639- KP792642).

Analyses of the Y-chromosomal STRs: Analyzed Y chromosomal STRs were found to be monomorphic. Sequences of the STRs were submitted to GenBank (KR152637- KR152639). The repetitive motifs and the allele sizes obtained from present study were listed in Table 5.
Table 5. The allele sizes, the repeat motifs and the accession numbers of the Y-chromosomal STRs.

Tablo 5. Y-kromozomal STR'ların allel büyüklügü, tekrar deseni ve ulaşım kodları.

\begin{tabular}{llll}
\hline Loci & Repeat motif & Allele & $\begin{array}{l}\text { Accession } \\
\text { number }\end{array}$ \\
\hline Eca.YP9 & $(\mathrm{AT})_{4}(\mathrm{GT})_{9}(\mathrm{CA})_{3}$ & 190 & KR152637 \\
Eca.YE1 & $(\mathrm{AC})_{2} \mathrm{C}(\mathrm{AC})_{8}$ & 195 & KR152638 \\
Eca.YM2 & $(\mathrm{CA})_{10}$ & 109 & KR152639 \\
\hline
\end{tabular}

\section{Discussion and Conclusion}

Turkish Statistical Institute (19) reported that donkey population has dramatically reduced in Turkey, while the donkey population was 809.000 head in 1994 , it declined to 170.503 head in 2014 , thus it means almost $79 \%$ reduction (19). Three different types of donkey are characterized in Turkey and there is not sufficient data on two types, Merzifon and Karakacan, except Anatolian type, which is the most prevalant (22). Anatolian donkeys show the general morphologic features such as coat color and body size with other well-known donkey types of world. The values of haplotype and nucleotide diversity $\quad(h=0.756 \pm 0.0500$ and $\pi=0.1688 \pm 0.0012)$ obtained from D-loop sequences of Anatolian donkey population were found to be moderately high, indicating plentiful genetic diversity. Otherwise when $h$ and $\pi$ values for D-loop region were compared with different donkey populations, Anatolian donkey populations found to be lesser than Ethiopian donkeys ( $h=0.903 \pm 0.032$ and $\pi=0.020 \pm 0.003$ ) reported by Kefena et al. (9), Balkan donkey breeds $(\mathrm{h}=0.982 \pm 0.002$ and $0.017 \pm 0.009)$ reported by Pérez-Pardal et al. (17), Chinese donkey breeds $(0.9055 \pm 0.0170$ and $0.0228 \pm 0.0117)$ reported by Chen et al. (3); while they were found to be higher than Spanish donkey breeds with values of average 0.421 and 0.007 (1). If it is taken into account the mitochondrial genetic diversity values of the other livestock raised in Turkey, such as goats and cattle, above-mentioned results of Anatolian donkey are unfamiliar $(12,16)$. It is suggested that this result in contrast to the livestock could be referred to drastically decrease of the donkey population in a short period as well as the possibility of the different domestication centers.

However diversities of the Cypriot donkey population $(h=0.524 \pm 0.209$ and $\pi=0.00176 \pm 0.001)$ were found dramatically reduced than those in Turkey. These donkeys are freely mating and neither selected nor hunted, thus only natural selection has affected their genetic diversity. However the number of the Cypriot donkeys is drastically reducing as well as the Anatolian donkeys (11). Hamrick et al. (7) reported that 800 donkeys were in Karpaz peninsula in 2003.

Only $35 \%$ of the Anatolian donkeys were clustered in Clade 1, while the remaining $65 \%$ and $100 \%$ of the Cypriot donkeys were clustered in Clade 2. This 
observation was concordant with the frequency of mtDNA lineages obtained from Turkish domestic donkeys, published by Beja-Pereira et al. (2). According to current researches, it is concluded that Nubian wild ass is putative ancestor of the donkeys from Clade 1 and there is a probable interbreeding between wild and domestic donkeys, which is causing to gene flow of several maternal haplotypes from the wild $(10,17)$. However, despite the Clade 2 is found to be closest to Somali lineage, there is still unknown about the ancestor lineage of the Clade 2 (10). Similarly, in the present study, Clade 2 was genetically divergent from Somali lineage, by $63 \%$ of the bootstrap value and from Asiatic wild asses. Thus, they were excluded from to be ancestor of Anatolian and Cypriot donkey populations.

According to the cytochrome b sequences results, AND2 was defined as the most frequent haplotype either Anatolian (55\%) or Cypriot donkeys (100\%). But AND1 is more recently contributed to Anatolian donkeys. The relatively high determination of haplotypes belonging to Clade 2 and AND2 in Cypriot donkey population is interesting. As the Cyprus is geographically isolated island in contrast to Turkey, donkey population expansion could be in different time periods. In Turkey, new haplotypes from the wild asses interacted with domestic donkeys through the human migrations, trades or wars, causing the mixture of the lineages, while the Cypriot donkeys was affected from those factors in a limited manner. However it cannot be excluded that natural selection affected the frequencies of the different lineages through bottleneck effects, which have led to increase of haplotypes from Clade 2 and AND1 together in the Cypriot population.

Single nucleotide polymorphisms (SNPs) and STRs localizing on the $\mathrm{Y}$ chromosome show a paternal contribution to evolutionary and phylogeographic studies, like mitochondrial DNA (mtDNA) represent to maternal history (4). Equine Y-chromosomal STRs analyzed in Anatolian and Cypriot donkey populations were found to be monomorphic, as consistent with Ling et al. (13). However, genotyped Anatolian and Cypriot donkey populations showed different alleles from those. Ling et al. study (13) identified alleles with 111, 196 and 192, Ferrando et al. study (5) identified alleles with 110/112, 196 and 191, Wallner et al. study (21) identified alleles with 110/112, 197 and 191 for Eca.YM2, Eca.YP9 and Eca.YE1, respectively. This can be explained by the following reasons; firstly it could be originated from the differences on the genotyping devices' sensitivities though they have the same allelic compositions, and secondly the contribution of different paternal lineages to the domestication. Therefore, the standardization of the STRs on Y chromosome would be beneficial. However, the results showed that the paternal history for Y chromosome with other gene regions could be more efficiently established.

As conclusion, this study represents the first documentation of the genetic Anatolian and Cypriot donkey populations. The higher number of sampling from different regions of the Turkey and Cyprus may reduce the possible negative effects of the sampling bias. Moreover, it is concluded that more assessment of the ancient sequences from Anatolia and Cyprus may shed light to mystery ancestor of the Clade 2.

\section{References}

1. Aranguren-Mendez J, Beja-Pereira A, Avellanet R, et al. (2004): Mitochondrial DNA variation and genetic relationships in Spanish donkey breeds (Equus asinus). JBAG, 121, 319-330.

2. Beja-Pereira A, England PR, Ferrand N, et al. (2004): African origins of the domestic donkey. Science, 304, 1781-1781.

3. Chen SY, Zhou F, Xiao H, et al. (2006): Mitochondrial DNA diversity and population structure of four Chinese donkey breeds. Anim Genet, 37, 422-431.

4. Cinar Kul B, Bilgen N, Lenstra JA, et al (2015): $Y$ chromosomal variation of local goat breeds of Turkey close to the domestication centre. JBAG, DOI: 10.1111/jbg.12154.

5. Ferrando A, Casas M, Jordana J (2011): Analysis of $Y$ chromosome genetic variability of six Spanish donkey breeds with three microsatellite markers. In XIV Jordanas Sobre Produccion Animal, Zaragoza,(479-481).17-18 May 2011, Espana.

6. Hall (1999): BioEdit: a user-friendly biological sequence alignment editor and analysis program for Windows 95/98/NT. In Nucleic acids symposium series, 41, pp 9598.

7. Hamrick RG, Pirgalioglu T, Gunduz S, et al. (2005): Feral donkey Equus asinus populations on the Karpaz peninsula, Cyprus. Eur J Wildl Res, 51, 108-116.

8. Hutchison, CA, III, Newbold JE, SS, Potter SS, et al. (1974): Maternal inheritance of mammalian mitochondrial DNA. Nature, 251, 536-538.

9. Kefena E, Dessie T, Tegegne A, et al. (2014): Genetic diversity and matrilineal genetic signature of native Ethiopian donkeys (Equus asinus) inferred from mitochondrial DNA sequence polymorphism. Livest Sci, 167, 73-79.

10. Kimura B, Marshall FB, Chen S, et al. (2011): Ancient DNA from Nubian and Somali wild ass provides insights into donkey ancestry and domestication. Proc R Soc B, 278, 50-7.

11. Kugler W, Grunenfelder HP, Broxham E (2007): Donkey breeds in Europe. Inventory, Description, Need for Action, Conservation Report-2008. St. Gallen, Switzerland.

12. Kul BC, Ertugrul O, (2011): mtDNA diversity and phylogeography of some Turkish native $g$ oat breeds. Vet $\mathbf{J}$ Ankara Univ, 58, 129-134.

13. Ling Y, Ma Y, Guan W, et al (2010): Identification of $Y$ chromosome genetic variations in Chinese indigenous horse breeds. J Hered, 101, 639-643. 
14. Leigh JW, Bryant D, (2014): PopART: Full-feature software for population genetics. Available from: http://popart.otago.ac.nz (11.01.2015).

15. Librado P, Rozas J, (2009): DnaSP v5: A software for comprehensive analysis of DNA polymorphism data. Bioinformatics, 25, 1451-1452.

16. Özdemir M, Dogru Ü, (2009): Determination of Phylogenetic Relationships of Turkish Native Cattle Breeds with Other Cattle Breeds Using Mitochondrial DNA D-loop Sequence Polymorphism. Asian Australas J Anim Sci, 22, 955-961.

17. Pérez-Pardal L, Grizelj J, Traoré A, et al. (2014): Lack of mitochondrial DNA structure in Balkan donkey is consistent with a quick spread of the species after domestication. Anim Genet, 45, 144-7

18. Tamura K, Stecher G, Peterson D, et al. (2013). MEGA6: molecular evolutionary genetics analysis version 6.0. Mol Biol Evol, 30, 2725-2729.

19. TurkStat (2015): Livestock statistics. Available from: http://www.turkstat.gov.tr (21.01.2015).
20. Vilà C, Leonard JA, Beja-PereiraA, (2006): Genetic documentation of horse and donkey domestication, 342353. In Zeder MA (Ed), Documenting domestication, University of California Press, Berkeley, CA, USA

21. Wallner B, Piumi F, Brem G, et al., (2004): Isolation of $Y$ chromosome-specific microsatellites in the horse and cross-species amplification in the genus Equus. J Hered, 95, 158-164.

22. Yilmaz O, Trevor RJ (2013): The domestic livestock resources of Turkey: Notes on donkeys. Anim Plant Sci, 23, 651-656.

23. Zeder MA, (2006): (Ed), Documenting domestication, University of California Press, Berkeley, CA, USA.

Geliş tarihi: 27.03.2015 / Kabul tarihi: 24.04.2015

\section{Address for correspondence:}

Bengi Çınar Kul, DVM, PhD, Assist. Prof. Dr. Ankara University,

Faculty of Veterinary Medicine, Department of Genetics, 06110, Dışkapı, Ankara, TURKEY.

e-mail:bkul@ankara.edu.tr 